6 Stefansson H, Ophoff RA, Steinberg S, Andreassen OA, Cichon S, Rujescu D, et al. Common variants conferring risk of schizophrenia. Nature 2009; 460 : 744-7.

7 Tyrer P, Oliver-Africano PC, Ahmed Z, Bouras N, Cooray S, Deb S, et al. Risperidone, haloperidol, and placebo in the treatment of aggressive challenging behaviour in patients with intellectual disability: a randomised controlled trial. Lancet 2008; 371: 57-63.
8 International Mental Health Research Network. Madrid Declaration: Searching for a Coordinated European-wide Effort in Mental Health Research. Cibersam, 2010 (http://www.cibersam.es/MadridDeclaration).

9 Global Forum for Health and Research. Monitoring Financial Flows for Health Research: The Changing Landscape of Health Research for Development. Global Forum for Health Research, 2006.

10 Knapp M. Hidden costs of mental illness. Br J Psychiatry 2003; 183: 477-8.

\title{
extra
}

\section{Shakespeare and post-traumatic stress disorder}

\section{Glin Bennet}

We are used to Shakespeare's compact and accurate descriptions of mental states. In A Midsummer Night's Dream (5.1.21) Theseus gives an example of how raised anxiety can distort the accuracy of perception:

Or in the night, imagining some fear,

How easy is a bush supposed a bear!

On a larger scale, in Henry IV, Part 1 (2.3.86) Shakespeare has given an account of what could be called post-traumatic stress disorder (PTSD), four centuries before the condition was formulated, and years before the word stress acquired its present usage. Hotspur's wife, Kate, was complaining about her husband's regular involvement in mortal combats and his consequent odd behaviour:

O, my good lord, why are you thus alone?

For what offence have I this fortnight been

A banish'd woman from my Harry's bed?

Tell me, sweet lord, what is't that takes from thee

Thy stomach, pleasure and thy golden sleep?

Why dost thou bend thine eyes upon the earth,

And start so often when thou sit'st alone?

Why hast thou lost the fresh blood in thy cheeks;

And given my treasures and my rights of thee

To thick-eyed musing and curst melancholy?

In thy faint slumbers I by thee have watch'd,

And heard thee murmur tales of iron wars:

speak terms of manage [horsemanship] to thy bounding steed;

Cry 'Courage! to the field!' And thou hast talk'd

of sallies and retires, of trenches, tents,

of palisadoes, frontiers, parapets,

of basilisks, of cannon, culverin,

Of prisoners' ransom and of soldiers slain,

And all the currents of a heady fight.

Thy spirit within thee hath been so at war,

And thus hath so bestirr'd thee in thy sleep,

That beads of sweat have stood upon thy brow

Like bubbles in a late-disturbed stream;

And in thy face strange motions have appear'd,

Such as we see when men restrain their breath

on some great sudden hest. 0 , what portents are these?

some heavy business hath my lord in hand,

And I must know it, else he loves me not.

But could this account meet the criteria to make a diagnosis of PTSD, as required by DSM-IV-TR?

- Traumatic event: for most of us, any day in Hotspur's life would seem like a significant traumatic event, as mortal conflict and avoiding violent death were his regular experience. But the cumulative effect of such days perhaps should amount to a significant traumatic event, even for him.

- Re-experiencing: Hotspur's disturbed behaviour during sleep.

- Avoidance, emotional numbing etc.: Kate complains of her husband's lack of interest in sex, isolating himself, distancing himself from her and refusing to discuss his feelings.

- Increased arousal: difficulty in falling asleep and being generally agitated

- Prolonged duration of disturbance: Kate only refers to a fortnight of symptoms, but Hotspur's warlike lifestyle suggests a long history.

- Distress and impairment of function: there seems to have been definite impairment in his life with Kate, but he was apparently effective in his military activities, at least until he was killed in battle.

Kate's account seems to cover the main features of PTSD, so perhaps this is one of the disorder's earliest descriptions. 